Gintaras Juodzbalys

Hom-Lay Wang

\title{
Soft and hard tissue assessment of immediate implant placement: a case series
}

Key words: bone-implant interactions, bone regeneration, clinical assessment, clinical research, clinical trials, diagnosis, guided tissue regeneration, soft tissue-implant interactions

\author{
Authors' affiliation: \\ Gintaras Juodzbalys, Department of Oral and \\ Maxillofacial Surgery, Kaunas University of \\ Medicine, Kaunas, Lithuania \\ Hom-Lay Wang, Department of Periodontics and \\ Oral Medicine, School of Dentistry, University of \\ Michigan, Ann Arbor, MI, USA

\section{Correspondence to:} \\ Assoc. Prof. Gintaras Juodzbalys \\ Vainiku I2, LT-46383 \\ Kaunas \\ Lithuania \\ Tel./Fax: + 3703732 3I 53, GSM: + 370699 \\ 56540 \\ e-mail: gintaras@stilusoptimus.lt
}

Date:

Accepted 4 April 2006

To cite this article:

Juodzbalys G, Wang H-L. Soft and hard tissue

assessment of immediate implant placement: a case

series.

Clin. Oral Impl. Res. I8, 2007; 237-243

doi: I0.I I II/j.I600-050I.2006.0I3I2.X

\begin{abstract}
Objectives: The aim of this prospective study was to evaluate clinically and radiographically the success and esthetic result of immediate implant placement at the time of extraction.

Material and methods: Twelve patients with 14 titanium screw-shaped implants $(13-16 \mathrm{~mm}$ length and 4.3 or $5 \mathrm{~mm}$ diameters) were placed in the extraction sockets. Defects after implant placement were recorded, and then filled up with deproteinized bovine bone mineral, bioabsorbable collagen membrane, and absorbable pins. The defect was again reevaluated at second-stage surgery. Clinical and radiographic parameters of the peri-implant conditions were assessed at the moment of prosthesis placement and at 1-year follow-up.

Results: The cumulative implant survival and success rate was $100 \%$ after a 1-year observation period. Analysis of the esthetic result showed that the mean pink esthetic score (PES) was 11.1 (SD 1.35) at 1-year follow-up. At 1 year, 64.3\% papillae had a score of 2 and the remaining $35.7 \%$ score 3 according to the Jemt (1997) papillary index. Optimal value of width of the keratinized mucosa was recorded in 13 (92.9\%) implant cases in both periods of followup. At 1-year follow-up, the linear distance between implant-shoulder to the bone peaks remains stable with a mean of $2.62 \pm 0.2 \mathrm{~mm}$ at the mesial and $2.9 \pm 0.58 \mathrm{~mm}$ at the distal aspect.

Conclusion: Careful evaluation of potential extraction sites before immediate implant installation promotes optimal implant esthetics.
\end{abstract}

The progressive involution of the alveolar bone begins following tooth loss, and it is accompanied by a reduction in both the quality and quantity of hard and soft tissues. To estimate the appropriate time for implant insertion, it is essential to understand the healing events that occurred after tooth extraction (Bianchi \& Sanfilippo 2004). It was shown that after extraction of natural teeth, the greatest reduction of the alveolar bone occurs in the first 6 months to 2 years (Carlsson \& Rosenfeld I967; Araujo \& Lindhe 2005; Araujo et al. 2005). An estimate of $25 \%$ decrease in faciopalatal width occurs within the first year (Carlsson \& Persson 1967; Tallgren I972; Misch I990; deLange I995). For this reason, within the last decades, the 'gold standard' implant treatment protocol has been challenged by experiments, which aimed at shortening the treatment period and by reducing the number of surgical procedures. The literature has demonstrated that it is no longer needed to wait for complete healing of the extraction socket before implant placement (Lazarra I989; Knox et al. I99I; Lundgren et al. I992; Becker \& Becker I994; Lang et al. 
I994; Wilson et al. I998; Rosenquist \& Ahmed 2000; Hämmerle \& Lang 200I; Nemcovsky et al. 2002; Juodzbalys 2003; Bianchi \& Sanfilippo 2004). With this surgical approach, it allows a better final rehabilitation because it facilitates morphological ridge contour preservation as well as accurate prosthetic implant installation maintaining the natural tooth angle (Werbitt \& Goldberg I992). However, the study of Araujo et al. (2005) showed that the placement of an implant in the fresh extraction site obviously failed to prevent the re-modelling that occurred in the walls of the socket. It is suggested that the resorption of the socket walls that occurs following tooth removal must be considered in conjunction with implant placement in fresh extraction sockets.

Nevertheless, surgical procedure planning in the case of immediate implant placement must fulfill several pre-set clinical conditions. These include the following: implant primary stability, qualitative osseointegration, proper prosthetic location, and esthetic result. An absolute requirement is that $3-5 \mathrm{~mm}$ of implant must be inserted into the host bone to gain initial implant stability (Nemcovsky et al. 2002; Juodzbalys 2003).

Proper placement of an implant into a fresh alveolus will in most cases result in a gap between the occlusal part of the implant and the bone walls. To ensure osseointegration, various guidelines for the immediate implantation technique have been suggested. These include, but are not limited to, socket augmentation using various reconstructive materials, such as application of membranes, grafting materials, and bone-inductive substances (Lazarra I989; Block \& Kent I992; Becker \& Becker I994; Lang et al. I994; Shearer I995; Steenberghe et al. 2000; Hämmerle \& Lang 200I; Nemcovsky et al. 2002).

Although implant success, as measured through fixture osseointegration and restoration of function, is high, the procedures available to create esthetic implant 'success' are not always predictable (Kazor et al. 2004). To ensure optimal esthetic implant rehabilitation, the following prerequisites are considered essential: adequate bone volume (horizontal, vertical, and, contour), optimal implant position (mesio-distal, apico-coronal, bucco-lingual, and angulation), stable and healthy periimplant soft tissues, esthetic soft tissues contours, and ideal emergence profile (Jovanovic I997; Kazor et al. 2004). The level of bone support and the soft tissue dimensions around the implant-supported singletooth restoration are factors suggested to be important for the esthetic outcome of implant therapy (Belser et al. I998).

The aim of this case series study was to evaluate clinically and radiographically the esthetic outcome of immediate implants placed into extraction socket using the simultaneous guided bone regeneration (GBR) technique.

\section{Material and methods}

\section{Patients and implants}

Between June 2003 and October 2004, I 2 patients, eight men and four women (age
I7-49 years, mean $=28$ ), who received dental implants in the Department of Maxillofacial Surgery, University of Kaunas, were consecutively enrolled in the investigation. The general health status of all patients included in the study had been deemed to be satisfactory. Heavy smokers (more than Io cigarettes a day) were excluded.

Fourteen titanium screw-shaped implants (Replace Select ${ }^{\mathbb{R}}$, Nobel Biocare, Goteborg, Sweden) I3-16 mm in length with 4.3 or $5 \mathrm{~mm}$ diameters were immediately installed after extraction. Table I lists the causes for teeth extraction. They were root fracture, perforation, periapical infection, and untreatable caries. All surgeries were performed under local anesthesia. Totally, they were eight upper central incisors and six upper lateral incisors.

\section{Surgical protocol}

Tooth extraction and site assessment

After local anesthesia, teeth were gently extracted and extreme care was exercised to avoid fracture of the socket walls. In order to achieve optimal esthetic implant rehabilitation, the following soft tissue conditions were evaluated: soft tissue quantity, quality, and biotype. Soft tissue contour was characterized as adequate or compromised. The keratinized gingival width on the buccal side in the treatment area was determined using a millimeter standard periodontal probe (Hu-Friedy UNC, Chicago, IL, USA). Possible vertical changes of contour were recorded between planned extract tooth/root and adjacent teeth.

Table 1. Data for patients, defect sites, and implants

\begin{tabular}{|c|c|c|c|c|c|c|}
\hline Serial \# & Gender & Age (years) & Tooth \# & Reason for tooth extraction & $\begin{array}{l}\text { Implant } \\
\text { length }(\mathrm{mm})\end{array}$ & $\begin{array}{l}\text { Implant } \\
\text { diameter (mm) }\end{array}$ \\
\hline 1 & Male & 24 & 11 & Periapical infection & 13 & 5 \\
\hline 2 & Male & 30 & 11 & Root fracture & 13 & 4.3 \\
\hline 4 & Female & 42 & 12 & Periapical infection & 13 & 4.3 \\
\hline $5: 1$ & & & 11 & Root fracture & 13 & 4.3 \\
\hline $5: 2$ & Male & 31 & 21 & Periapical perforation & 16 & 4.3 \\
\hline $7: 2$ & Male & 28 & 12 & Root fracture & 16 & 4.3 \\
\hline 8 & Male & 22 & 22 & Periapical infection & 13 & 4.3 \\
\hline 9 & Female & 26 & 21 & Periapical perforation & 16 & 4.3 \\
\hline 10 & Male & 19 & 22 & Root fracture & 16 & 4.3 \\
\hline 11 & Male & 24 & 12 & Caries & 13 & 5 \\
\hline 12 & Female & 27 & 21 & Caries & 13 & 4.3 \\
\hline
\end{tabular}


Proper mesial and distal papilla appearance was evaluated when distinct papilla was noted. Soft tissue quality was determined as good when there were no recorded variations of color, consistence, and texture, and there was no periodontal infection. Gingival tissues biotype was characterized as thick ( $\geq$ I $\mathrm{mm}$ ), or thin (< I mm) gingival tissues.

The height of the alveolar process and the available remaining bone for dental implant insertion above the extraction socket apex was estimated by the orthopantomogram, taking into consideration an average X-ray magnification of $20 \%$ (Cranex-3, Soredex, Finland). The socket height measurements were taken in a vertical plane at the points of the extraction socket, from the tip of the extraction socket margin to the nasal sinus in the upper jaw. The height of the available remaining bone for dental implant insertion was measured from the socket apex to the maxillary or nasal sinus.

The width of the extraction socket was measured with a millimeter standard periodontal probe intra-orally in mesio-distal and labio-palatal directions at the socket margin. The vertical position and bone loss of the labial plate was recorded from the cemento-enamel junction (CEJ) line of the adjacent teeth to the tip of the extraction socket labial plate. Intra-dental bone peak height was recorded as the distance from the tip of the intra-dental bone peak to the alveolar process crest mid-line. The mesiodistal dimension between adjacent teeth was measured in the mesio-distal direction between the most prominent points at the CEJ level. Measurements were recorded to the nearest I mm mark.

Extraction socket facial bone thickness was estimated with ridge-mapping calipers. Measurements were performed in a vertical plane in the labial plate at points I to $6 \mathrm{~mm}$ from the labial plate tip. This technique minimized discrepancies. The smallest measurement was accepted as the width of the socket labial plate. Extraction socket contour and possible tooth/root labial angulation were evaluated using a diagnostic wax-up.

Dental implant placement and intra-operative examination

All implants were placed in a similar manner. Briefly, implants were placed in the

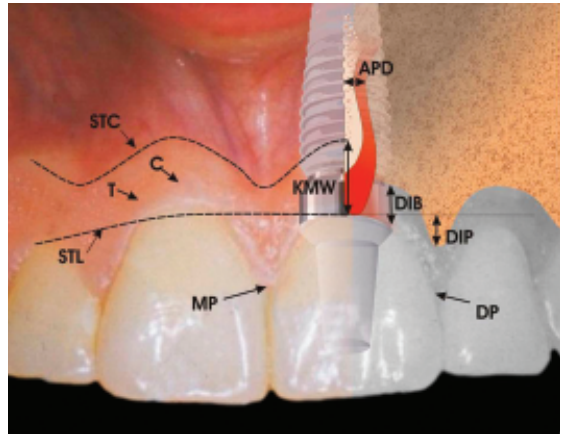

Fig. I. Clinical (left side) and radiographic measurements (right side) of peri-implant soft and hard tissues: mesial papilla (MP), distal papilla (DP), soft tissue level (STL), soft tissue contour (STC), keratinized mucosa width (KMW), soft tissue color $(C)$, soft tissue texture $(T)$, the distance between implant-shoulder to the alveolar bone level (DIB), and the distance between implant-shoulder to the bone peaks (DIP).

optimal three-dimensional position: apicocoronally, 2-3 $\mathrm{mm}$ below the adjacent CEJ line (Saadoun \& Landsberg I997); buccolingually, 3-4 $\mathrm{mm}$ from the outside buccal flange (Kazor et al. 2004); and mesio-distally, $\geq \mathrm{I} .5 \mathrm{~mm}$ away from adjacent teeth (Ohrnell et al. I988; Adell et al. I990).

At the time of implant placement, the vertical dehiscence defect extension from the shoulder of the implant to the first bone-to-implant contact was measured. The clinical measurements were assessed in millimeters at six sites around each implant: mesio-buccal (MB), buccal (B), disto-buccal (DB), disto-palatal (DP), palatal $(\mathrm{P})$, and mesio-palatal $(\mathrm{MP})$, using a millimeter standard periodontal probe. Measurements were recorded to the nearest I mm mark. Figure I illustrates all clinical measurements recorded in this study.

The remaining defects and dehiscences after implant placement were filled up, using deproteinized bovine bone mineral (Bio-Oss ${ }^{\mathbb{B}}$, Geistlich AG, Wolhusen, Switzerland). The Bio-Oss ${ }^{\circledR}$ and implant cover screw were covered with a collagen membrane (Bio-Gide ${ }^{\mathbb{B}}$, Geistlich AG). The membrane was extended onto the intact bony walls of the defect and held securely in place by resorbable pins (Resor Pin ${ }^{\mathbb{B}}$, Geistlich AG). Soft tissue deficiency was corrected using connective tissue grafting. Connective tissue was retrieved from the palatal vault (Bianchi \& Sanfilippo 2004).

After the soft tissue adaptation, complete coverage of the extraction wound was obtained using closure with monofila- ment sutures. One hour before surgery, the patients were given $2 \mathrm{~g}$ V-penicillin and post-operatively $2 \mathrm{~g}$ was given twice a day for 7 days. Chlorhexidine $0.2 \%$ oral rinses were prescribed twice daily for 2 weeks. The sutures were removed after Io days. After 6 months, re-entry surgery was performed. The same clinical measurements were again recorded.

Implant success and esthetic result evaluation The suprastructures consisted of I4 single cemented crowns that were seated 6 months post-surgically. Implant esthetic result evaluation was performed after prosthetic rehabilitation and at I-year follow-up.

The criteria of success set for this study were chosen according to Albrektsson et al. (1986) and included the following: absence of persistent subjective complains, such as pain, foreign body sensation, and/or dysestesia; absence of peri-implant infection with suppuration; absence of mobility; absence of a continuous radiolucency around the implant; and vertical bone loss less than $\mathrm{I} .5 \mathrm{~mm}$ in the first year of function.

The health and stability of soft tissues was evaluated using the modified plaque index (MPI) and the modified bleeding index (MBI) proposed by Mombelli et al. (1987). Peri-implant probing depth (PD) was performed at four sites for each implant, buccal, palatal, mesial, and distal.

Interproximal marginal bone level was measured from standardized periapical radiographs that were obtained using a customized Rinn film holder $\left(\mathrm{XCP}^{\mathbb{R}}\right.$ Instruments, Rinn Corporation Elgin, IL, USA) with a rigid film-object-X-ray source coupling to a beam-aiming device in order to achieve reproducible exposure geometry. The evaluation of the radiographs was performed in a linear fashion using a standardized computerized system to determine the mesial and distal distance from the implant shoulder to the alveolar bone level (DIB). Wherever there was evidence of two different bone levels, the one situated more apically was measured. Bone peaks height was evaluated by calculating the linear distance between implant-shoulder to the bone peaks (DIP), mesially and distally to the implant.

Esthetic and harmonious implant-supported restoration conformance to the preexisting dentition was evaluated according 
to Furhauser et al. (2005). The pink esthetic score (PES) was evaluated at I-year follow-up. The PES is based on seven variables: mesial papilla, distal papilla, soft tissue level, soft tissue contour, alveolar process deficiency, soft tissue color, and texture. Each variable was assessed with a 2-I-O score, with 2 being the best and o being the poorest score.

Dental papilla preservation was evaluated clinically using a papillary index described by Jemt (I 997). The papillary index designates five different levels of papilla height. Measurements were made from the reference line connecting the highest gingival curvatures of the implant crown restoration and the adjacent tooth or crown on the buccal side. The mesial and distal papillae were evaluated for completeness, incompleteness, or absence. All other variables were assessed by comparison with a reference tooth, i.e., the corresponding tooth (anterior region) or a neighboring tooth (pre-molar region). The highest possible score reflecting a perfect match of the peri-implant soft tissue with that of the reference tooth was I4.

Additionally, the width of the keratinized mucosa (KMW) on the buccal side was evaluated in millimeters.

\section{Statistical analysis}

Simple statistical analyses were performed using the SPSS/PC + version Iо.о.I program (SPSS Inc., Chicago, IL, USA). Means and standard deviations were calculated. The Wilcoxon's matched pairs signed rank test was applied to detect differences between diagnostic and re-entry measurements. The level of statistical significance was set at $P=0.05$.

\section{Results}

\section{Peri-implant parameters and implant success}

Diagnostic extraction socket measurements after implant placement showed that the largest mean vertical defect of $5.17 \mathrm{~mm}$ (SD $0.75 \mathrm{~mm}$, range $4-6 \mathrm{~mm}$ ) was found in case no. I I (Table 2). The mean vertical defect extension of all sites was $4.15 \mathrm{~mm}$ (SD $0.7 \mathrm{~mm}$, range $2.5^{-}$ $5.8 \mathrm{~mm}$ ). After 6 months of healing, at reentry, the mean vertical extension of all sites was $0.45 \mathrm{~mm}$ (SD $0.3 \mathrm{~mm}$, range oI.I $\mathrm{mm})$. The considerable decrease in bone defect of $89.6 \%$ (SD $7.9 \%$ ) was statistically significant $(P<0.05)$.

At the moment of prosthesis placement and I year after prosthetic rehabilitation, all implants were stable and painless, and no discomfort and/or altered taste was recorded. There was no sign of continuous radiolucency around the implants. The cumulative implant survival and success rate was I00\% after the I-year observation period.

Most of the patients exhibited good oral hygiene performance during both follow-up periods: a MPI score o was registered for $7 \mathrm{I} .4 \%$ and score I for $28.6 \%$ of implant sites at the moment of prosthesis placement. One year later, score o was registered for $64.3 \%$ of implant sites. MBI score o was registered for $78.6 \%$ of the implant sites and remained stable after I year of function. The frequency distribution of various PDs showed that at the time of prosthesis placement, all implant sites had a PD ranging between $2 . \mathrm{I}$ and $3 \mathrm{~mm}$. One year later, 7 I.5\% implant sites with a PD ranging between $3 . \mathrm{I}$ and $3.5 \mathrm{~mm}$ dominated.

Analysis of radiographic bone level showed that the mean DIB was $0.57 \mathrm{~mm}$ (SD $0.3 \mathrm{~mm}$ ) at the period of prosthesis placement (Table 3). This demonstrated good peri-implant defect fill after GBR. At I-year follow-up, the mean DIB was $1.72 \mathrm{~mm}$ (SD $0.43 \mathrm{~mm}$ ). Nine out of I4 $(64.3 \%)$ of implant sites demonstrated a marginal bone level between o.I and $0.5 \mathrm{~mm}$ at the period of prosthesis placement (Table 3). The same percentage $64.3 \%$ of implant sites (9/I4) was noted, with DIB levels ranging between I.I and 2.0 $\mathrm{mm}$ after I year. The registered mean vertical bone loss for all implants after I year of function was $1.16 \mathrm{~mm}$ (SD $0.25 \mathrm{~mm}$; Table 3). The highest number $(78.6 \%)$ of implant sites (II/I4) demonstrated a vertical bone loss of I.I-I. $5 \mathrm{~mm}$. At the moment of prosthesis placement, the mean DIP for all patients was $2.96 \mathrm{~mm}$ (SD $0.43 \mathrm{~mm}$, range $2.2-3.6 \mathrm{~mm}$ ) at the mesial aspect and $3.28 \mathrm{~mm}$ (SD $0.60 \mathrm{~mm}$, range $2.0-4.1 \mathrm{~mm}$ ) at the distal aspect (Table 4). At I-year follow-up, DIP was almost stable and the mean DIP was $2.62 \mathrm{~mm}$ (SD $0.2 \mathrm{~mm}$, range $2-3 . \mathrm{Imm}$ ) at the mesial aspect and $2.9 \mathrm{~mm}$ (SD $0.58 \mathrm{~mm}$, range $1.9-4 \mathrm{~mm}$ ) at the distal aspect.

Table 2. Diagnostic and re-entry vertical defect measurements, including mean values and ranges (mm), and percentage of defect fill

\begin{tabular}{|c|c|c|c|c|c|c|c|}
\hline \multirow[t]{2}{*}{ Serial \# } & \multicolumn{3}{|c|}{ Diagnostic vertical defect extension (mm) } & \multicolumn{3}{|c|}{ Re-entry vertical defect extension (mm) } & \multirow[t]{2}{*}{ Defect fill (\%) } \\
\hline & Mean & SD & Range & Mean & SD & Range & \\
\hline 1 & 3.83 & 1.47 & $2-6$ & 0.33 & 0.52 & $0-1$ & 91.3 \\
\hline 3 & 4.67 & 1.37 & $3-7$ & 0.50 & 0.55 & $0-1$ & 89.3 \\
\hline 4 & 2.67 & 0.82 & $2-4$ & 0 & 0 & $0-0$ & 100 \\
\hline $5: 1$ & 4.17 & 0.75 & $3-5$ & 0.33 & 0.52 & $0-1$ & 92 \\
\hline $5: 2$ & 4.50 & 1.05 & $3-6$ & 0 & 0 & $0-0$ & 100 \\
\hline $7: 2$ & 3 & 1.26 & $1-4$ & 0 & 0 & $0-0$ & 100 \\
\hline 8 & 4 & 0.89 & $3-5$ & 1 & 0.89 & $0-2$ & 75 \\
\hline 9 & 4.17 & 1.60 & $2-6$ & 0.50 & 0.55 & $0-1$ & 88 \\
\hline 10 & 3.83 & 1.47 & $2-5$ & 0.33 & 0.52 & $0-1$ & 91.3 \\
\hline 11 & 5.17 & 0.75 & $4-6$ & 0.83 & 0.75 & $0-2$ & 83.9 \\
\hline 12 & 4 & 1.41 & $2-6$ & 0.83 & 0.75 & $0-2$ & 79.2 \\
\hline
\end{tabular}

Mean, mean of all patients; SD, standard deviation. 
Table 3. Marginal bone level (DIB) and marginal bone loss ( - DIB) measured in radiographs for 14 implants at the moment of prosthesis placement and 1 year of function (DIB = mesial and distal distance from implant shoulder to the alveolar bone level; - DIB = vertical bone loss)

\begin{tabular}{lllll}
\hline Serial \# & $\begin{array}{l}\text { Implant location } \\
\text { (tooth no.) }\end{array}$ & $\begin{array}{l}\text { DIB prosthesis } \\
\text { placement }(\mathrm{mm})\end{array}$ & $\begin{array}{l}\text { DIB after } \\
1 \text { year }(\mathrm{mm})\end{array}$ & $\begin{array}{l}\text { - DIB after } \\
1 \text { year }(\mathrm{mm})\end{array}$ \\
\hline 1 & 11 & 0.4 & 1 & 0.6 \\
2 & 11 & 0.5 & 1.3 & 0.8 \\
3 & 21 & 0.6 & 2 & 1.4 \\
4 & 12 & 0.3 & 1.7 & 1.4 \\
$5: 1$ & 11 & 0.4 & 1.6 & 1.2 \\
$5: 2$ & 21 & 0.2 & 1.6 & 1.4 \\
6 & 11 & 1.2 & 2.4 & 1.2 \\
$7: 1$ & 11 & 0.4 & 1.5 & 1.1 \\
$7: 2$ & 12 & 0.3 & 1.4 & 1.1 \\
8 & 22 & 1 & 2.1 & 1.1 \\
9 & 21 & 0.5 & 1.8 & 1.3 \\
10 & 22 & 0.4 & 1.3 & 0.9 \\
11 & 12 & 0.9 & 2.4 & 1.5 \\
12 & 21 & 0.9 & 2.1 & 1.2 \\
Mean & 0.57 & 1.72 & 1.16 \\
SD & 0.3 & 0.43 & 0.25 \\
\hline Mean, mean of all implant sites; SD, standard deviation. & \\
\hline
\end{tabular}

Table 4. Intra-dental bone peaks height (DIP) measured in radiographs for 14 implants at the moment of prosthesis placement and 1 year of function (DIP = mesial (M) and distal (D) distance from implant shoulder to the intra-dental bone peaks)

\begin{tabular}{|c|c|c|c|c|c|}
\hline \multirow{2}{*}{$\begin{array}{l}\text { Serial } \\
\#\end{array}$} & \multirow{2}{*}{$\begin{array}{l}\text { Implant location } \\
\text { (tooth No.) }\end{array}$} & \multicolumn{2}{|c|}{ DIP prosthesis placement $(\mathrm{mm})$} & \multicolumn{2}{|c|}{ DIP after 1 year $(\mathrm{mm})$} \\
\hline & & $M$ & $D$ & $M$ & $D$ \\
\hline 1 & 11 & 2.9 & 3 & 2.8 & 2.8 \\
\hline 2 & 11 & 3.3 & 3.6 & 3.1 & 3 \\
\hline 3 & 21 & 3.2 & 4 & 2.9 & 3.8 \\
\hline 4 & 12 & 2.6 & 2.7 & 2.3 & 2.5 \\
\hline $5: 1$ & 11 & 3.5 & 4.1 & 2.9 & 4 \\
\hline $5: 2$ & 21 & 2.8 & 3.3 & 2.6 & 3.2 \\
\hline 6 & 11 & 3.3 & 3.6 & 3 & 3.4 \\
\hline $7: 1$ & 11 & 3.1 & 3.4 & 2.7 & 3.1 \\
\hline $7: 2$ & 12 & 3.6 & 3.9 & 3 & 3.7 \\
\hline 8 & 22 & 2.2 & 2 & 2 & 1.9 \\
\hline 9 & 21 & 2.3 & 2.5 & 2 & 2.4 \\
\hline 10 & 22 & 2.5 & 2.9 & 2.5 & 2.8 \\
\hline 11 & 12 & 2.9 & 3.4 & 2.3 & 3.2 \\
\hline 12 & 21 & 3.2 & 3.6 & 2.6 & 3.5 \\
\hline Mean & & 2.96 & 3.28 & 2.62 & 2.9 \\
\hline SD & & 0.43 & 0.6 & 0.36 & 0.58 \\
\hline
\end{tabular}

\section{Esthetic results}

At I-year follow-up, the mean PES was I I.I (SD I.35). Analysis of PES showed that in most cases there were incomplete mesial and distal papillae and alveolar process deficiency: nine $(64.3 \%)$ and six $(42.9 \%)$ cases, respectively. A minor discrepancy of soft tissue margin level of $\mathrm{I}-2 \mathrm{~mm}$ was registered in three (2 $1.4 \%$ ) cases (Table 5).

Analysis of the Jemt (I997) papillary index showed no class o, class I, or class 4 inter-proximal papillae at I-year followup. Eighteen $(64.3 \%)$ papillae had a score of 2 , while the remaining Io papillae $(35.7 \%)$ had a score of 3 .

It was considered that the optimal mean value of KMW for esthetic result should be
I.I $6 \mathrm{~mm}$ (SD $0.25 \mathrm{~mm}$ ). This is in line with previously reported data (Albrektsson et al. I986, Schropp et al. 2005). Soft s grafting ensured sufficient vestibular keratinized mucosa width (more than $2 \mathrm{~mm}$ ) in 92.9\% cases and good emergence crown alignment was achieved. At I-year followup, the mean PES was II.I (SD I.35) and this is consistent with the study of Furhauser et al. (2005), where the mean PES was $9.46( \pm 3.8 \mathrm{I}$ SD). Furthermore, the cumulative implant survival and success rate for all pooled implants was IOO $\%$ after the I-year observation period. This is in agreement with previously published papers (Lazarra I989; Becker \& Becker I994; Lang et al. I994; Mensdorf-Pouilly et al. I994; Rosenquist \& Ahmed 2000; Hämmerle \& Lang 200I; Nemcovsky et al. 2002; Bianchi \& Sanfilippo 2004). These findings suggest that successful immediate tooth replacement with dental implants using GBR is possible especially when the extraction site is carefully evaluated and planned. Furthermore, this implantation method reduces the time from tooth extraction to complete rehabilitation, when compared with classical delayed and late implantation protocols. Resorption of the thin buccal wall and the alveolar crest after extraction may be reduced by a timely insertion of the implant (Werbitt \& Goldberg I992).

Placement of an implant into a fresh extraction socket will, in most cases, result in a gap between the occlusal part of the implant and the bony walls. When dehiscence bony defects were exceeding $2 \mathrm{~mm}$, they were grafted with deproteinized bovine bone xenografts (Bio-Oss ${ }^{\circledR}$, Geistlich AG). The small peri-implant bone defects were completely healed without the use of GBR procedures and this is consistent with Covani et al. (2003). Hence, it is essential to evaluate the bone volume: horizontal, vertical, and contour before implant placement. To achieve implant primary stability, available bone beyond the extraction socket margin should be at least $3 \mathrm{~mm}$ (Nemcovsky et al. 2002; Juodzbalys 2003).

Accepted minimal width of the extraction socket labial plate was I-2 $\mathrm{mm}$. This agrees with Spray et al. (2000) and Kazor et al. (2004): a buccal bone wall thickness of at least $\mathrm{I}-2 \mathrm{~mm}$ is critical, which may necessitate hard tissue augmentation.

It has been demonstrated that the presence or absence of bone crest influences 
Table 5. PES evaluation scores for 14 implant restorations at 1 year of function

\begin{tabular}{|c|c|c|c|c|c|c|c|c|}
\hline Serial \# & $\begin{array}{l}\text { Mesial } \\
\text { papillae }\end{array}$ & $\begin{array}{l}\text { Distal } \\
\text { papillae }\end{array}$ & $\begin{array}{l}\text { Level of soft } \\
\text { tissue margin }\end{array}$ & $\begin{array}{l}\text { Soft tissue } \\
\text { contour }\end{array}$ & $\begin{array}{l}\text { Alveolar process } \\
\text { deficiency }\end{array}$ & $\begin{array}{l}\text { Soft tissue } \\
\text { color }\end{array}$ & $\begin{array}{l}\text { Soft tissue } \\
\text { texture }\end{array}$ & $\begin{array}{l}\text { Mean } \\
\text { score }\end{array}$ \\
\hline 1 & 1 & 1 & 2 & 2 & 2 & 2 & 2 & 12 \\
\hline 2 & 1 & 1 & 2 & 1 & 2 & 2 & 2 & 11 \\
\hline 4 & 2 & 2 & 1 & 2 & 1 & 1 & 1 & 10 \\
\hline $5: 1$ & 2 & 2 & 2 & 2 & 2 & 2 & 2 & 14 \\
\hline $5: 2$ & 1 & 1 & 1 & 2 & 2 & 1 & 2 & 10 \\
\hline $7: 2$ & 2 & 2 & 2 & 2 & 1 & 2 & 2 & 13 \\
\hline 8 & 1 & 1 & 2 & 2 & 1 & 1 & 2 & 10 \\
\hline 9 & 1 & 1 & 2 & 1 & 1 & 2 & 2 & 10 \\
\hline 10 & 2 & 2 & 2 & 2 & 1 & 2 & 2 & 13 \\
\hline 11 & 1 & 1 & 2 & 2 & 2 & 1 & 1 & 10 \\
\hline 12 & 1 & 1 & 2 & 1 & 2 & 2 & 2 & 11 \\
\hline Mean of all implant restorations & & & & & & & & 11.1 \\
\hline
\end{tabular}

SD, standard deviation; PES, pink esthetic score.

the appearance of papillae between implants and adjacent teeth (Choquet et al. 200I). Jemt (I997) proposed an index to assess the size of the inter-proximal gingival papillae adjacent to single implant restorations. Our data showed that is $(64.3 \%)$ papillae had a score of 2 while the remaining ro papillae $(35.7 \%)$ had a score of 3 according to the Jemt (I997) papillary index. No class 0 , class I, or class 4 inter-proximal papillae at I-year followup were noted. This implies that the technique that we used here was able to maintain the papillae height and appearance.

A PES to assess the esthetic and harmonious implant-supported restoration conformance to the pre-existing dentition was evaluated according Furhauser et al. (2005). The mean PES was II.I (SD I.35) at Iyear follow-up. In most cases, there were incomplete mesial and distal papillae and alveolar process deficiency: nine (64.3\%) and six $(42.9 \%)$ cases, repectively. A minor discrepancy of soft tissue margin level of I$2 \mathrm{~mm}$ was registered in three $(2 \mathrm{I} .4 \%)$ cases. This is in agreement with Schropp et al. (2005), who reported early placement of single-tooth implants may be preferable to a delayed implant placement technique in terms of early generation of inter-proximal papillae and the achievement of an appropriate clinical crown height. However, no difference in papilla dimensions was seen at I.5 years after seating of the implant crown (Schropp et al. 2005).

Another prerequisite to successful implant rehabilitation, both functionally and esthetically, is the proper location of the implant fixture and restoration in the edentulous space (Kazor et al. 2004). Implants should be placed in the optimal position mesio-distally, apico-coronally, and buccopalatally. The mesio-distal dimension between adjacent teeth should be 6-9 $\mathrm{mm}$ to ensure minimal (I.5 mm) distance between implant fixture and adjacent teeth (Ohrnell et al. I988; Adell et al. I990). Natural buccal and proximal restorative contour can be ensured by correctly orienting the implant in a bucco-palatal position. A minimum space of $2 \mathrm{~mm}$ should be maintained on the buccal side in front of the external implant collar surface. Pursuance of the above-mentioned requirements in our study ensured good functional and esthetic results.

\section{Conclusions}

Careful evaluation of potential extraction sites before immediate implant installation promotes optimal implant esthetics. Ex- traction sites with compromised soft tissue and bone volume can be successfully corrected using guided bone regeneration and connective tissue graft.

要旨:

目的: 本前向き試験の目的は抜歯後即時イン プラント埋入の成績と審美的結果を臨床的 およびX線像によって評価することであった。 材料と方法: 患者 12 人において合計 14 本の チタン製スクリュー・インプラント（13-16 $\mathrm{m} \mathrm{m}$ 長、 4.3 または $5.0 \mathrm{~mm}$ 径) を抜歯窩に 埋入した。インプラント埋入後の久損部に除 蛋白牛骨ミネラルを充填し、生体吸収性コラ ーゲン・メンブレンと吸収性ピンを用いた。 二次手術時に欠損の再評価を行った。インプ ラント周囲の臨床的及びX線上のパラメー ターを補緅物装着時と 1 年後の観察時に評 価した。

結果 : 1 年間の観察期間後の累積インプラン 卜存続率と成功率は $100 \%$ であっ。審美的 結果の分析では、ピンク・エステティック・ スコア（PES）は 1 年後に平均 11.1（SD1.35） であった。

Jemt の乳頭インデックス (1997) に基づくと、 1 年後に歯間乳頭の $64.3 \%$ はスコアが 2 、残 り $35.7 \%$ は 3 であった。2 回の評価時に、1 3 本のインプラント $(92.9 \%)$ で、最適な角 化粘膜の幅が記録された。 1 年後の評価時に、 インプラント・ショルダーから骨頂までの直 線距離は、近心側が $2.62 \pm 0.2 \mathrm{~mm}$ 、遠心側 が $2.9 \pm 0.58 \mathrm{~mm}$ で、安定していた。 結論：インプラント即時埋入に先立つ、抜歯 予定部位の入念な評価は、インプラントの最 適な審美性を促進する。

\section{References}

Adell, R., Eriksson, B., Lekholm, U., Branemark, P.I. \& Jemt, T. (I990) Long-term follow-up study of osseointegrated implants in the jaws. International Journal of Oral e) Maxillofacial Implants 5: 347-359.
Albrektsson, T., Zarb, G., Worthington, P. \& Eriksson, A.R. (I986) The long-term efficacy of currently used dental implants: a review and proposed criteria of success. International
Journal of Oral ↔) Maxillofacial Implants $\mathbf{I}$ : I I-25.

Araujo, M.G. \& Lindhe, J. (2005) Dimensional ridge alterations following tooth extraction. An 
experimental study in the dog. Journal of Clinical Periodontology 32: 21 2-2 I8.

Araujo, M.G., Sukekava, F., Wennstrom, J.L. \& Lindhe, J. (2005) Ridge alterations following implant placement in fresh extraction sockets: an experimental study in the dog. Journal of Clinical Periodontology 32: 645-652.

Becker, B.B. \& Becker, W. (1994) Promotion around e-PTFE-augmented implants placed in immediate extraction sockets. In: Buser, D., Dahlin., C. \& Schenk, R.K., eds. Guided Bone Regeneration in Implant Dentistry. Ist edition, I37-I55. Chicago: Quintessence Publishing Co Inc.

Belser, U.C., Buser, D., Hess, D., Schmid, B., Bernard, J.P. \& Lang, N.P. (I998) Esthetic implant restorations in partially edentulous patients - a critical appraisal. Periodontology I7: I 32-I 50.

Bianchi, A.E. \& Sanfilippo, F. (2004) Single-tooth replacement by immediate implant and connective tissue graft: a I-9 year clinical evaluation. Clinical Oral Implants Research I 5: 269-277.

Block, M.S. \& Kent, J.N. (I992) Prospective review of integral implants. Dental Clinics of North America 36: 27-37.

Carlsson, R.A. \& Persson, A.L. (1967) Morphologic changes of the mandible after extraction and wearing of dentures. A longitudinal, clinical and $\mathrm{x}$-ray cephalometric study covering 5 years. Odontologic Review I 8: 27-54.

Choquet, V., Hermans, M., Adriaenssens, P., Daelemans, P., Tarnow, D.P. \& Malevez, C. (200I) Clinical and radiographic evaluation of the papilla level adjacent to single-tooth dental implants. A retrospective study in the maxillary anterior region. Journal of Periodontology 72: 1364-I37I.

Covani, U., Cornelini, R. \& Barone, A. (2003) Bucco-lingual bone remodeling around implants placed into immediate extraction sockets: a case series. Journal of Periodontology 74: 268-273.

deLange, G.L. (I995) Aesthetic and prosthetic principles for single tooth implant procedures: an overview. Practical Periodontology and Aesthetic Dentistry 7: 5 I-6I.

Furhauser, R., Florescu, D., Benesch, T., Haas, R., Mailath, G. \& Watzek, G. (2005) Evaluation of soft tissue around single-tooth implant crowns: the pink esthetic score. Clinical Oral Implants Research I6: 639-634.

Hämmerle, C.H.F. \& Lang, N.P. (200I) Single stage surgery combining transmucosal implant placement with guided bone regeneration and biore- sorbable materials. Clinical Oral Implants Research 12: 9-I 8.

Jemt, T. (I997) Regeneration of gingival papillae after single-implant treatment. International Journal of Periodontics and Restorative Dentistry $\mathbf{1 7}$ : 327-333.

Jovanovic, S.A. (I997) Bone rehabilitation to achieve optimal aesthetics.. Practical Periodontics and Aesthetic Dentistry 4: 4I-5I.

Juodzbalys, G. (2003) Instrument for extraction socket measurement in immediate implant installation. Clinical Oral Implants Research I4: I44-I 49.

Kazor, C.E., Al-Shamari, K., Sarment, D.P., Misch, C.E. \& Wang, H.-L. (2004) Implant plastic surgery: a review and rationale. Journal of Oral Implantology 30: 240-254.

Knox, R., Candill, R. \& Meffert, R. (I99I) Histologic evaluation of dental endosseous implants placed in surgically created extraction defects. International Journal of Periodontology and Restorative Dentistry II: 365-376.

Lang, N.P., Brägger, U., Hämmerle, C.H.F. \& Suttter, F. (1994) Immediate transmucosal implants using the principle of guided tissue regeneration. Clinical Oral Implants Research 5: I 54I63.

Lazarra, R.J. (I989) Immediate implant placement into extraction sites: surgical and restorative advantages. International Journal of Periodontology and Restorative Dentistry 9: 333-343.

Lundgren, D., Rylander, H., Andersson, M., Johansson, C. \& Albrektsson, T. (I992) Healing-in of root analogue titanium implants placed into extraction sockets. An experimental study in the beagle dog. Clinical Oral Implants Research 3: I36-I 43 .

Mensdorf-Pouilly, N., Haas, R., Mailath, G. \& Watzek, G. (1994) The immediate implant: a retrospective study comparing the different types of immediate implantation. International Journal of Oral e) Maxillofacial Implants 9: 57 I-578.

Misch, C.E. (I990) Divisions of available bone in implant dentistry. International Journal of Oral Implantology 7: 9-17.

Mombelli, A., van Oosten, M.A., Schurch, E. Jr \& Land, N.P. (I987) The microbiota associated with successful or failing osseointegrated titanium implants. Oral Microbiology and Immunology 2: I45-I 5 I.
Nemcovsky, C.E., Artzi, Z., Moses, O. \& Gelernter, I. (2002) Healing of marginal defects at implants placed in fresh extraction sockets or after 4-6 weeks of healing. A comparative study. Clinical Oral Implants Research I3: 4IO-4I9.

Ohrnell, L.O., Hirsch, J.M., Ericsson, I. \& Branemark, P.I. (I988) Single-tooth rehabilitation using osseointegration. A modified surgical and prosthodontic approach. Quintessence International I9: 87I-876.

Rosenquist, B. \& Ahmed, M. (2000) The immediate replacement of teeth by dental implants using homologous bone membranes to seal the sockets: clinical and radiographic findings. Clinical Oral Implants Research II: 572-582.

Saadoun, A.P. \& Landsberg, T.C. (I997) Treatment classifications and sequencing for post extraction implant therapy: a review. Practical Periodontology and Restorative Dentistry 9: 933-94I.

Schropp, L., Isidor, F., Kostopoulos, L. \& Wenzel, A. (2005) Interproximal papilla levels following early versus delayed placement of single-tooth implants: a controlled clinical trial. International Journal of Oral $\oplus$ Maxillofacial Implants 20 : 753-76I.

Shearer, B.H. (I995) Osseointegrated implants: a review of the literature. International Dental Journal 45: 26I-268.

Spray, J.R., Black, C.G., Morris, H.F. \& Ochi, S. (2000) The influence of bone thickness on facial marginal bone response: stage I placement through stage 2 uncovering. Annals of Periodontology 5: II $19-\mathrm{I} 28$.

Steenberghe, D., Callens, A., Geers, L. \& Jacobs, R. (2000) The clinical use of deproteinized bovine bone mineral on bone regeneration in conjunction with immediate implant installation. Clinical Oral Implants Research II: 2 I0-2 I 6.

Tallgren, A. (1972) The continuing reduction of the residual ridges in complete denture wearers: a mixed-longitudinal study covering 25 years. Journal of Prosthetic Dentistry 27: I2O-I 32.

Werbitt, M.J. \& Goldberg, P.V. (I992) The immediate implant: bone preservation and bone regeneration. International Journal of Periodontics and Restorative Dentistry 3: 206-217.

Wilson, T.G., Schenk, R., Buser, D. \& Cochran, D. (I998) Implants placed in immediate extraction sites: a report of histologic and histometric analysis of human biopsies. International Journal of Oral ↔) Maxillofacial Implants I3: 333-34I. 